\title{
INTERACTIVE MULTIMEDIA USE OF GAMES MODEL ON IPS SCHOOL STUDY LIST
}

Febby Fajar Nugraha

Education Program of Elementary School of Universitas Kuningan

\author{
febbyfajar92@yahoo.com
}

\begin{abstract}
ABSTARCT
The development of information and communication technologies have a major impact in many areas of life, one of which is education. Learning use the media, is a strategy favored by students, particularly those related to technology. Because no denying that the interest of students to current technologies is huge. It can be seen from the children of school age, who loss of learning time because they are pre occupied with the world of technology, such as playing games, mobile phones and computers. Indonesian Internet Service Provider Association (APJII) conducted a survey of online game players active in Indonesia, the result is there are about 6 million online game players. This proves that Indonesian children have an interest in the game. The change of curriculum in Indonesia from 2006 curriculum (Curriculum Education Unit) into a curriculum 2013, providing a wide range of implications for the learning process, one of which is the subject of Information and Communication Technology (ICT). In curriculum 2013, ICT subjects be erased, it's means not stand alone but rather merged or combined with other subjects. In elementary school curriculum needs subjects that are combined with computer lessons (Guha \&Leonard, 2002). Therefore, teachers must be able to create methods that can capitalize on technology such as computer media in the learning process.
\end{abstract}

Keywords: Computer, Interactive multimedia games model, Social Studies, Elementary school, and Understanding of concepts.

\section{INTRODUCTION}

In the SD curriculum it is necessary to include subjects united with computer lessons (Guha \& Leonard, 2002). Therefore, teachers should be able to create learning methods that can take advantage of technology such as computers as a medium in the learning process. As said by Rusman, et al. (2012) that the media is a tool that allows students to understand and understand something easily to remember it in a long time compared with the delivery of subject matter by way of face to face and lectures without the tools or learning media.

Improving the quality of learning with the application of ICT (Information Communication and Technology) is done by developing learning applications in interactive learning model fun and exciting for students (Warsihna, 2005). The dynamic nature of computer use is an important key to introducing cognitive play activities (Olive, 2000). The learning objectives of IPS in schools according to Permendiknas No.22 (Depdiknas, 2006) include the following: (1) Understanding the concept of IPS, explaining the interrelationship between concepts and applying concepts or algorithms widely, accurately, efficiently, and appropriately in problem solving; (2) Using understanding of patterns and traits, performing IPS manipulations in generalizing, compiling evidence, or explaining IPS ideas and statements; (3) solve problems that include the ability to understand problems, design an IPS 
model, complete the model and interpret the solutions obtained; (4) Communicating ideas with symbols, tables, diagrams, or other media to clarify circumstances or problems; (5) Have an appreciation of the use of IPS in life, namely memilii curiosity, attention and interest in studying social studies, as well as resilience and confidence in problem solving.

Based on the above objectives the teacher should have a modern perspective in the process of teaching and learning, because in essence IPS does not lie in the mastery of IPS as a science only, but how to use the IPS to achieve success in life. In addition to giving priority to the development of the ability of understanding in an effort to develop students' scientific attitude, also required the ability of communication. Because through communication, a person will be able to express his ideas, findings or even his feelings towards others (Nature, 2012).The ability of mathematical communication as a social activity and as a tool of thought recommended by experts to continue to be grown developed by the students (Umar, 2012). Mathematical understanding is closely related to mathematical communication. Students who already have the ability of mathematical understanding is also required to be able to communicate, so that understanding can be utilized by others. With the ability of mathematical communication students can also take advantage of IPS concepts that have been understood by others. By communicating his mathematical ideas to others, one can improve his mathematical understanding.

\section{METHODS}

The approach used in this research is descriptive approach. This study only examines and collects sources related to the Use of Interactive Multimedia Model Games on Elementary IPS Elementary School that is expected to provide benefits for the implementation of learning IPS in elementary school.

\section{RESULTS AND DISCUSSION}

Several studies have been conducted on the use of computers for IPS learning, that learning with interactive multimedia proved to increase enthusiasm or motivation and learning outcomes and make students comfortable in learning (Seo \& Bryant, 2010; Milovanoviu, 2013), In line with Kariadinata (2012) research that interactive media in IPS learning is very important to improve the quality of learning, which in turn will be able to prepare students to have high-level skills to face the competitiveness in the future. In addition to improving learning motivation, interactive multimedia game model can also increase the activity of mathematical behavior of students who experience attention deficit hyperactivity disorder (ADHD) (Jackson, et al, 2013). 
Many low-grade students feel that IPS lessons are difficult (Guha \& Leonard, 2002), which is one of the reasons for teachers to provide motivation in different ways. To make students motivated, enjoy learning IPS, and have a positive attitude towards IPS, teachers need to make a fun learning strategy. If the students already like IPS, then at least students' mathematical understanding and communication can increase as well. Because what happened during this time teachers only provide mathematical understanding procedurally, not conceptually. Likewise with the mathematical ability, the results showed that the mathematical communication skills of Indonesian students are still not good (Prayitno, 2012), most students have difficulty in solving problem-solving problems and translate the problems into everyday life into the model IPS .

Nusir, et al (2012) conducted research on multimedia programs in low class, the results showed that the method was effective to get students' attention, especially when cartoon characters were included in the program. One of the strategies to improve students' motivation in IPS learning is by using interactive multimedia learning media model games. This model is interesting to study due to the high interest of Indonesian people to the games. The use of multimedia for learning provides a better and longer understanding for students, providing attractiveness, both used as a method of problem solving, improving students' skills, critical thinking, and explorative (Koesnandar, 2006). In addition, students enjoy learning to use computers, because they think they will play instead of learning (Ladel, 2006). In Social Studies, computers help us to visualize abstract concepts, so that children can better understand the concepts we describe. If interactive multimedia can improve students' learning motivation, it is expected that the media can also improve understanding and mathematical communication.

\section{Computers as Learning Media}

Media comes from the word medius which means middle, intermediary, or introduction. Media is a tool that has the function of delivering messages (Boove, in Rusman, 2011). Media in teaching and learning process has two important role that is: (1) Media as teaching aid or referred as dependent media because media position here as a tool; And (2) Media as a learning suber used independently by learners or called independent media. Rusman (2011, p.63) divides the learning media into five types, including: visual media, audio media, audio-visual media, media presentation groups, and media objects and interactive media based on computers.

Along with the development of technology, information, and communication, also developing process or method of learning today. These technological developments 
encourage renewal efforts in the learning process. The term computer derived from the Latin is computare which means counting. Computers are actually electronic media that can receive information in the form of digital input by using binner code in the application program, and display the output of information in the form of electronic data visualization (Rusman, 2011).

Initially computers are used only for purposes of counting in administrative activities only, but currently computer applications are very possible to be used as a learning tool for educational purposes. Utilization of computer technology has contributed a lot to the learning process one of them is the application of computer-based learning. Benefits of computers for educational purposes according to Arsyad (in Rusman, 2011, p.47) are:

a. Computers can accommodate students who are slow to receive lessons because they can afford a more affective climate in a more individualized, never forgetful, never bored, very patient way of executing the instructions the program wants to use.

b. Computers can stimulate students to do exercises, perform laboratory activities or simulations because of the availability of animated graphics, colors, and music, which can add realism.

c. Control is in the hands of students, so that the rate of student learning can be adjusted with the level of mastery. In other words the computer can interact with students individually, for example by asking and responding answers.

d. The ability to record student activities during the use of learning programs, provides better opportunities for individual learning and the development of each student can always be monitored.

e. Can connect with, and control other equipment such as interactive CDs, videos, and others with control programs from the computer.

The role of the computer as a medium of learning is to become the main source (major resource) in implementing the learning program in schools, through student computers can run applications supported programs also with other supporting facilities such as internet.

\section{Interactive Multimedia Model Games}

The definition of multimedia proposed by Ivers and Barron (2002, p.2) is:"Multimedia is the use of several media to present information. Combination may include text, graphics, animation, pictures, video, and sound."In line with the above opinion, Koesnandar (2006, p.75) also suggests that interactive multimedia learning is a medium of learning which is a combination of various elements of the media consisting of text, graphics, poto, animation, video, and sound presented interactively. Other opinions expressed by Rusman (2011, p. 10), multimedia-based learning is a learning activity that leverages 
computers to create and combine text, graphics, audio, motion pictures (video and animation) by combining links and tools that enable the user to navigate, Interact, create, and communicate.

From the three opinions above can be concluded that interactive multimedia can be interpreted as learning media in the form of video or animation presented interactively, where students can use them individually using a computer in accordance with the level of ability to train certain skills and competencies. Multimedia model games or games is a learning program that emphasizes the presentation of the game with the content of lesson material in it. This model makes students involved in win or lose situations, there is reward or punishment. The emphasis of this game model teletak on the effort to maximize teaching and learning activities on an ongoing basis in the form of interaction between students and learning materials in the form of games. A lot of students, especially elementary students, are quite able to uncover the learning procedures are packed in the form of games (Darmawan, 2012).

This model was developed based on the basis of fun learning. Multimedia model games are able to provide a more relaxed conditions that students perceived when learning. In this co-star the students will not experience learning fatigue, because the material presented is really the form of the game as well as the online games that kids love today. The games model belongs to a computer-based learning group with a branching programmed teaching pattern, in which information or material is presented in the form of game units, followed by questions and / or responses to the success or failure of completing the games in question. Student responses are analyzed by computer and then compared with answers that are then given a response.

Nuryadi (2010, p.5) mentions several advantages of multimedia for IPS learning, including:

a. Interesting and fun for students.

b. Effective and efficient.

c. The material has been structured according to the lesson plan that the teacher made.

d. Files made easy to share and can be a summary of home study materials for students.

e. Make it easier to communicate instructional materials to parents so that they can assist parents in assisting children home-study.

\section{Primary School IPS Learning}

IPS is a science that has an important role in human life. IPS is a subject that is often considered difficult by students, especially elementary school students. The concept of IPS is 
an abstract concept, while the developmental phase of elementary school students according to Piaget (in Santrock, 2012) is at a concrete operational stage. This means that elementary students need real objects or examples related to their daily lives.

The mistake often made by elementary school teachers in teaching IPS is that they directly provide procedural understanding to students. Students should be given a thorough understanding of the concept first. Based on this, teachers are expected to teach IPS by providing experiences with concrete objects that are known to students to facilitate students to understand the concept of IPS meaningfully.

\section{Ability to Understand Mathematical Concepts}

IPS is a science that can be used by someone in life. Therefore each individual must have mathematical mastery at a certain level. The mastery is not the satisfaction of IPS as a science, but the mastery of IPS skills. Kilpatrick (2001, pp. 116) formulated five general competencies of IPS, including: conceptual understanding, Procedural Fluency, Strategic Competence, Adaptive Reasoning, Productive Dispotition. The five competencies are the parts that affect each other and can not be separated from each other. One of the most important competencies is the conceptual understanding understanding. Understanding and mastery of a concept is a prerequisite for mastering the next concept. In line with Van de Walle (2008, p.26) which defines understanding as a measure of the quality and quantity of the relationship of an idea with an existing idea. Therefore it can be understood that the ability of mathematical understanding is a very basic thing in learning IPS to learn to be more meaningful.

IPS learning objectives in schools according to Permendiknas No. 22 of 2006, one of which is to understand the concept of IPS, explaining the inter-linkage of concepts and applying concepts or algorithms widely, accurately, efficiently, and appropriately in problem solving. The students 'knowledge and understanding of the IPS concept according to NCTM (1989, pp. 223) can be seen from the students' ability in (1) defining verbal and written concepts; (2) identifying making examples and not examples; (3) using models, diagrams, and symbols to present a concept; (4) converting a presentation into another; (5) recognize the various meanings and interpretations of concepts; (6) identify the properties of a concept and recognize the conditions that define a concept; (7) compare and differentiate the concepts. In line with the concept of understanding indicators according to the 2006 curriculum, namely:

1. Redefine a concept.

2. Classify objects according to certain traits (in accordance with the concept).

22 | INTERACTIVE MULTIMEDIA USE OF GAMES MODEL ON IPS SCHOOL STUDY LIST 
3. Provide examples and non-examples of concepts.

4. Present the concept in the form of a mathematical representation.

5. Develop sufficient terms or conditions of a concept.

6. Using, utilizing, and selecting certain procedures or operations.

7. Apply the concept or algorithm of a problem solving.

Mathematical understanding is important for learning IPS meaningfully. Understanding the concept of mathematics is an important foundation for thinking in solving the problems of social studies and daily problems. Understanding the concept is the competence shown by the students in understanding the concept and in the procedure accurately, efficiently, and appropriately. Students who can understand mathematical concepts well, will be easier to apply in various life problems. Kariuki and Morris (2013) argue that the standard in IPS study now focuses on acquiring conceptual understanding, not just teaching methodologies or giving formulas. In IPS learning in the classroom, students tend to be directed only to the ability to use formulas, memorize formulas, so IPS is only for working on problems.

\section{CONCLUSION}

In learning, the use of multimedia is very supportive of active and constructive learning, because by using this media students can construct their own knowledge. In IPS learning, the use of multimedia can help teachers to transfer abstract concepts to semiconcrete by visualizing in the form of drawings or diagrams. In line with Moreno (2002), that multimedia program allows students to work easily to represent something complex.

The use of interactive multimedia games especially models, can be an alternative for elementary school teachers in choosing an IPS learning strategy. Expected by using interactive multimedia, students can enjoy IPS, improve motivation to learn, so that the concept of IPS understanding can also be improved. Teachers not only provide procedural understanding only. Because correct concept, students will memapu think in solving the problems of IPS or problems encountered in everyday life.

\section{ACKNOWLEDGMENTS}

Researchers would like to thank all those who have supported this research both in terms of morale and material, especially at the University of Kuningan. 


\section{REFERENCES}

Darmawan, Deni. (2012). Teknologi Pembelajaran. Bandung: PT Remaja Rosdakarya.

Depdiknas. 2006. Peraturan Menteri Pendidikan Nasional RI No. 22 Tahun 2006 Tentang Standar Isi untuk Satuan Pendidikan Dasar dan Menengah. Jakarta: Depdiknas.

Guha, S. \& Leonard, J. (2002). Motivation in elementary mathematics: How students and teachers benefit from computers. TechTrends, 46 (1), 40-43.

Ivers, K.S., \& Barron, A.E. (2002). Multimedia Projects in Education: Designing, Producing, and Assessing. Connecticut: Libraries Unlimited.

Jackson, AT.Dkk. (2013).An evaluation of interactive tabletops in elementary mathematics education.Education Tech Research Dev, 61, 311-332.

Kariadinata, Rahayu. (2012). Aplikasi Multimedia Interaktif dalam Pembelajaran IPS Sebagai Upaya Meningkatkan Kemampuan Berpikir Matematik Tingkat Tinggi Siswa SMA.(Disertasi).Sekoalh Pasca Sarjana Universitas Pendidikan Indonesia, Bandung.

Koesnandar, Ade. (2006). Pengembangan software pembelajaran multimedia interaktif.Jurnal Teknodik, 18 (X), 75-83.

Kilpatrick, Jeremy. Dkk. (2001).Adding It Up: Helping Children Learn Mathematics. Washington, DC: National Academy Press.

Ladel, Silke. (2006). An academic experiment on the use of computers in elementary school mathematics classrooms. ZDM, 38 (6), 464-471.

Milovanoviu, M. dkk.(2013). Application of interactive multimedia tools in teaching mathematics - examples of lessons from geometry.The Turkish Online Journal of Educational Technology, 12 (1), 12-31

Moreno, Roxana. (2002). Who Learns Best with Multiple Representations? Cognitive Theory Implications for Individual Differences in Multimedia Learning. Amerika: ERIC

NCTM.(1989). Curriculum and Evaluation Standards for School Mathematics.Restori, Va: NCTM.

Nusir, dkk. (2012). Studying the impact of using multimedia interactive programs at children ability to learn basic math skills. ActaDidacticaNapocensia, 5 (2), 17-32. ISSN 20651430.

Olive, John. (2000). Computer tools for interactive mathematical activity in the elementary school.International Journal of Computers for Mathematical Learning, 5 , 241-262. Netherland: Kluwer Academic Publisher.

Prayitno, S., Suwarsono, S., \&Siswono, T.Y. (2013).Identifikasi indicator kemampuan komunikasi matematissiswa dalam menyelesaikan soal IPS berjenjang pada tiap-tiap jenjangnya.KNPMV, Himpunan IPS Indonesia. 384-389.

Rusman, Kurniawan, D., \&Riyana, C. (2011).Pembelajaran berbasi Teknologi Informasi dan Komunikasi. Jakarta: PT Raja grafindo Persada.

Santrock, John W. (2012). Life Span Development. Jakarta: PT Erlangga.

Seo, You-Jin.\& Bryant, D. (2010).Multimedia CAI program for students with mathematics difficulties.Remedial and Special Education, 33 (4), 217-225. DOI: $10.1177 / 0741932510383322$.

Umar, Wahid. (2012). membangunkemampuankomunikasi matematis dalam pembelajaran IPS.Jurnal Ilmiah Program Studi IPS STKIP Siliwangi Bandung, 1 (1), 1-9.

Warsihna, Jaka. (2005). "Dilema" pemanfaatan teknologi komunikasi dan informasi (ICT) untuk meningkatkan mutu pendidikan.Jurnal Teknodik, 16 (10), 60-76.

Van De Walle, Jhon A. (2008). IPS Sekolah Dasar dan Menengah (Dr. Suyono, M.Si.Terjemahan).Jakarta:Erla 